\title{
SOLAR ENERGY UTILIZATION IN WATER DISTILLATION
}

\author{
Tayel,S.A.* El-Nakib, A.A.* El-Meseery, A.A.** Badr, M.M.***
}

\section{ABSTRACT}

The aim of this study is to design and evaluate some different units of solar stills constructed as follow a: (control unit, preheating unit, air blower unit and air suction unit). Some different parameters, which affect on the productivity of solar still units, were studied as brine depth, slope angle of glass cover, feed water and cover material. The results show that the highest productivity was with preheating unit $\left(6030 \mathrm{~cm}^{3} / \mathrm{m}^{2}\right.$.day) with brine depth $2 \mathrm{~cm}$, cover slope angle $20^{\circ}$, and feed water time every two hours.

\section{INTRODUCTION}

$\mathrm{F}$ Tresh water is a necessity for the continuity of life. It is also the key to man's prosperity. Although there is a sufficient amount of water quality where it is needed for specific purposes.

Nowadays, there is growing interest in the developing countries towards the possibilities of utilization of solar energy and their practical application in the agricultural sector.

Solar distillation is the most appropriate process for fresh water supply, especially for small communities in arid zones.

Ahamed and Schmid (2002) said that fresh water is the most important source for life on the earth .In the Egyptian deserts and rural areas, there is a shortage of fresh water despite of the presence of large sources of brackish water. Solar energy is abundant in these remote areas of Egypt, where the amount of sunshine hours is around $3500 \mathrm{~h} /$ year.

Mathioulakis and Belessiotis (2003) indicated that the possibility of usage optimization of a simple solar still through incorporation in a multisource and multi-use environment was investigated. Concerning

* Prof. of Ag. Eng., Fac. of Ag., Al-Azhar Univ., Cairo.

** Assoc. Prof. of Ag. Eng., Fac. of Ag., Al-Azhar Univ., Cairo. ***Demonstrator of Ag. Eng. Dep., Fac. Ag. Al-Azhar Univ., Cairo. 
energy sources, the possibility to exploit a near by solar collector field and other energy sources is investigated, in order to increase productivity of the still. Influence of hot water draw-off in distilled water productively is investigated. Coupling of the still with external sources and additional uses are achieved with introduction of water tank, which operates as a thermal buffer.

Abd El-Salam (1996) found that the depth of water in channel is very important parameter. The optimum depth of the water layer is $4 \mathrm{~cm}$ and the depth should not be exceeding 10, because for more depth, the upper surface layers of water is exposed to vortices and water is carving out to the blower. On the other hand, the input heat from the sun at high water depth will not be sufficient to even heat the water, to a temperature at which any moisture can be transferred to the air.

Zabady (1997) mentioned that the total daily productivity decreased from 4646 to 4506,4416 , and $4323 \mathrm{~cm} 3 / \mathrm{m}^{2}$.day, with brine depth increased from 0.5 to $1.0,1.5$, and $2.0 \mathrm{~cm}$, respectively. The nocturnal production increased from 835 to 850,900 and $912 \mathrm{~cm}^{3} / \mathrm{m}^{2}$ when brine depth increased from 0.5 to $1.0,1.5$ and $2.0 \mathrm{~cm}$, respectively.

Talbert et al. (1970) indicated that plastic covered stills usually have sealed seams if necessary, and some types have clamped gaskets around the periphery. Some permeability exists in the plastic.

Ghoraba (1987) found that a reduction in base losses coefficient (by efficient insulation ) from 5.58 to $1.0 \mathrm{~W} / \mathrm{m}^{2} .{ }^{\circ} \mathrm{C}$ gives a bout $20 \%$ increase in output.

Moustafa et al. (1994) mentioned that the productivity of solar stills reaches its maximum value at an optimum cover slope. The slope depends the time of year, the location of the still, and the ambient conditions. An average slope of 20 to 25 degrees from the horizontal shows satisfactory results for a wide range of stills.

Rai and Tiwar (1983) found that the average daily production of distilled water, for a basin-type solar still coupled with a flat-plate collector, was $24 \%$ higher than that for a simple-basin solar still.

The objectives of this research are constructed and evaluated different units of solar stills. 


\section{MATERIALS AND METHODS}

\section{I-MATERIALS:}

Four different units of solar stills were constructed as follows (control unit, preheating unit, air blower unit and air suction unit).

The experiments were carried out on the roof area of the Agricultural Engineering Department. Faculty of Agricultural, Al-Azhar University, Nasr city, located at $\left(30^{\circ} 2^{\backslash} \mathrm{N}\right.$ and $\left.31^{\circ} 12^{\backslash} \mathrm{E}\right)$.

\section{- Basin solar still (control unit).}

The solar still consists of an evaporator with four sides of galvanized iron sheet of $0.6 \mathrm{~mm}$ thickness. The basin dimensions of the evaporator are 900 $\times 560 \mathrm{~mm}$. The still unit was isolated from the bottom and the sides by two layers of $3 \mathrm{~cm}$ of foam and $1.6 \mathrm{~cm}$ of counter wood. The space above the basin is completely enclosed with a transparent air-tight cover. A glass cover used had $3 \mathrm{~mm}$ thickness. The whole base set was painted with corrosion resistant paint, and from the inside a black paint was applied twice, this black paint was recommended to absorb the maximum amount of solar radiation incident which is expected to raise temperature as shown in fig.(1).

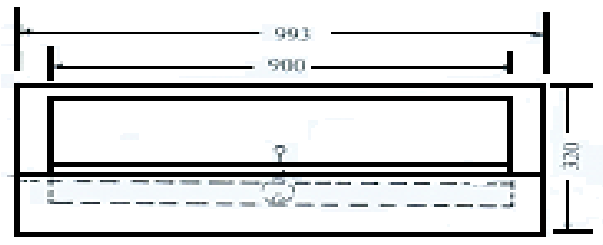

Elevation

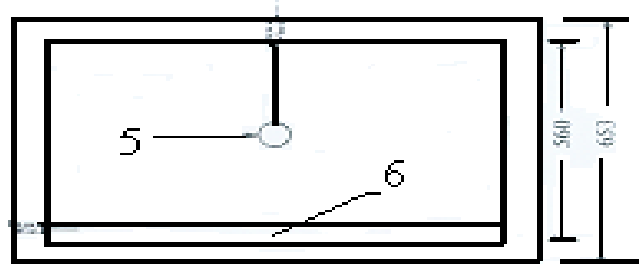

Plan

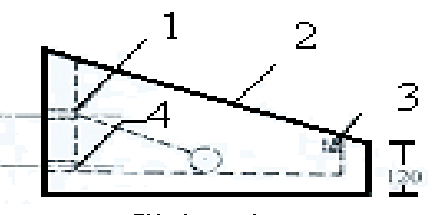

Side view 1 -brine supply 2-glass cover 3-outlet distilled water 4-drain 5-float 6-trough The dimension $(\mathrm{mm})$.

Fig. (1)

The inside walls of the unit are coated with white paint to reflect the radiation toward the basin. In the inner side of the still unit, all the connection cracks are filled with silicon sealant and glass cover is fixed with rubber seal in order to insure complete tightness and to prevent the water vapor from escaping. The still glass cover is placed on rubber 
gasket at both the set sides. Silicon rubber was applied to seal this connection properly to eliminate the vapor and air leakage. Plastic hoses are used to apply the still unit with the water through graduated glass bottles. In addition, there are other plastic hoses to blow and suck of air. A polyethylene plastic tank (200) liters was used to supply the units by saline water. The sun rays pass through the cover and are absorbed by the saline water and black tray. As the water temperature increases, evaporation takes place from the surface of water. The major quantity of water vapor condenses on the inner surface of glass cover forming a film.

\section{- Preheating unit.}

This unit is basin solar still connected with a flat- plate solar collector used to preheat saline water before entering the still unit. The flat-plate solar collector consists of $10 \mathrm{~m}$ hard copper tube $8 \mathrm{~mm}$ diameter. The tube was fixed to galvanized iron sheet of $0.6 \mathrm{~mm}$ thickness, which are absorber plate, of $0.5 \mathrm{~m}^{2}$ area. The absorber plate was insulated with two layers from insulation materials, $3 \mathrm{~cm}$ of foam and $1.6 \mathrm{~cm}$ of counter wood. The distance between the absorber plate and glass cover is $5 \mathrm{~cm}$. The copper tube and the absorber plate were painted with black paint. The flat-plate solar collector was covered also with glass sheet of $3 \mathrm{~mm}$ thickness. In this unit, there were four holes through the evaporator, one for brine supply, one for drain, one for outlets distilled water, and the last for thermocouple terminals. The water vapor condenses on the inner surface of the glass cover forming a film.

\section{- Air blower unit.}

The air blow unit was of the same structure as basin solar still, but it was connected with air blower). The blower was used to blow an air stream inside still unit at $0.9 \mathrm{~m} / \mathrm{s}$. The water vapor moves from inside the still unit to outside the still unit by air stream, then water vapor is condensed outside the still unit. In this unit, there were nine holes through the evaporator, one for water supply, one for drain, one for outlet of distilled water, one for thermocouples terminals, two for blow air stream and three for water vapor which comes from the still unit. Water vapor which is carried out the unit by air stream is condensed in outer condenser (heat exchanger) and the remainder on the inner surface of the glass covers in the same way as the control unit and preheating unit. 


\section{- Air suction unit.}

The air suction unit was also of the same structure of basin solar still but it was connected with the air suction pump, which is used to suck water vapor to outside still unit at $1.2 \mathrm{~m} / \mathrm{s}$, then water evaporation is condensed outside still unit. In this unit there are nine holes through the evaporator, one for brine supply, one for drain, one for outlets distilled water, one for thermocouple leads, two for air supply and three for the water vapor which comes from inside the still unit.The condensation of water vapor in this unit is the same way in the air blower unit.

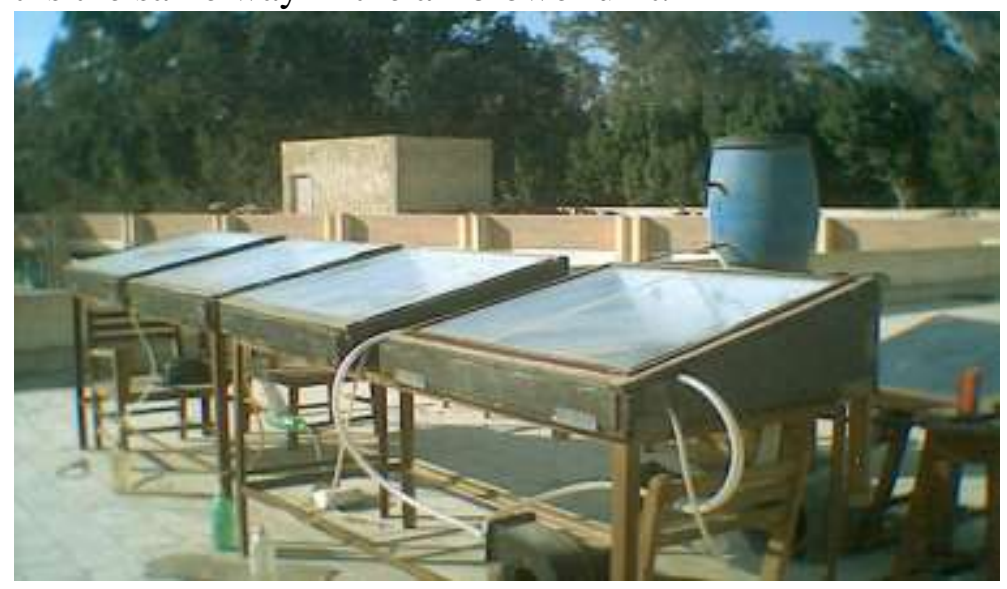

Fig. (2) Four solar still units.

\section{- Measuring instruments:}

\section{Solar intensity device.}

A Black and white pyranometer was constructed and tested by Ghanem (1989) and calibrated in the Solar Energy Department, National Research Center (NRC), Giza, Egypt. It was used to measure the instantaneous total solar radiation incident on the horizontal plane The output voltage of the pyranometer is converted to solar intensity as $\mathrm{mV}$. equivalent to 182.6 watt $/ \mathrm{m}^{2}$.

\section{Turbo meter.}

A Turbo meter was used to measure the air flow rate, which has 3ranges, miles per hour (0-99.9), feet per minute (0-8790) and meters per second (0-44.8). This device was made in (U.S.A).

\section{Thermocouple.}

Temperatures were measured by thermocouple wires, which were connected to a selector switch. It was connected as digital measurement to 
measure the temperature in degrees centigrade. The thermocouple used was of type "K". The thermocouple wires used were shielded chromelalumel (0.3mm diameter).

\section{EC meter.}

An EC meter was used to measuring water salinity in parts per million (ppm). Water salinity was measured at Soil and Water Department of the Faculty of Agriculture, Al-Azhar University.

\section{Graduated glass bottles.}

A graduated glass bottle (1 litter) was used to measure the amount of distilled water.

\section{II-METHODS:}

The still units were constructed at the workshop and tested at the solar energy laboratory of Agricultural Engineering Department. Faculty of Agricultural, Al-Azhar University, Nasr city, Cairo, located at $\left(30^{\circ} 2^{\backslash} \mathrm{N}\right.$ and $31^{\circ} 12 \mathrm{E}$ ) at summer of 2006 .

The following observations were recorded from 9 a.m. to 5 p.m. with an hour intervals: Ambiant air temperature $\left(\mathrm{T}_{\mathrm{a}}\right),{ }^{\circ} \mathrm{C}$, Saline water temperature $\left(\mathrm{T}_{\mathrm{w}}\right),{ }^{\circ} \mathrm{C}$, Bottom surface of basin temperature $\left(\mathrm{T}_{\mathrm{bo}}\right),{ }^{\circ} \mathrm{C}$, Space of inside still temperature $\left(\mathrm{T}_{\mathrm{s}}\right),{ }^{\circ} \mathrm{C}$, Inside glass cover temperature $\left(\mathrm{T}_{\mathrm{i}}\right),{ }^{\circ} \mathrm{C}$, Tank temperature $\left(\mathrm{T}_{\mathrm{t}}\right),{ }^{\circ} \mathrm{C}$, Saline water of preheating temperature $\left(\mathrm{T}_{\mathrm{p}}\right),{ }^{\circ} \mathrm{C}$, Air stream inlet to still temperature $\left(\mathrm{T}_{\mathrm{ai}}\right),{ }^{\circ} \mathrm{C}$, Air stream outlet from still temperature $\left(\mathrm{T}_{\mathrm{ao}}\right),{ }^{\circ} \mathrm{C}$, Solar still productivity rate $(\mathrm{Y}), \mathrm{cm}^{3} / \mathrm{m}^{2} . \mathrm{h}$, Intensity solar radiation $\left(\mathrm{S}_{\mathrm{i}}\right), \mathrm{W} / \mathrm{m}^{2}$ and Wind velocity $\left(\mathrm{V}_{\mathrm{w}}\right), \mathrm{m} / \mathrm{s}$.

The experiments were divided into four cases as follows.

1- Control unit. 2- Preheating unit. 3- Air blower unit. 4- Air suction unit.

Every case studied the effect of brine depth, glass cover tilt angle, the time of feed saline water and cover materials. Salt concentration of water was constant through the experimental time at (18500 ppm).

- Solar intensity (I) on the solar still unit.

The solar intensity was recorded every one hour from 9 a.m. to 5 p.m. by solar meter, and recorded in $\left(\mathrm{W} / \mathrm{m}^{2}\right)$.

\section{- Temperature on the solar still unit.}

The temperature of water, inner surface of the front cover, bottom surface of basin, and ambient air were observed and recorded directly using the digital thermocouple. 


\section{- Solar still productivity of distilled water.}

Productivity rate was estimated by measuring distilled water from the still, every one hour, from 9 a.m. to 5 p.m. by means of collecting the water in graduated mug. The daily productivity of solar still, or the daily yield $\left(\mathbf{Y}_{\mathbf{d}}\right)$ is defined as the total volume of distillate, in liters, produced by the still in a day per unit heat collector area, i.e.

$\mathbf{Y}_{\mathbf{d}}=$ (volume of distillate collected in day / heat collector area) $\mathrm{cm}^{3} / \mathrm{m}^{2}$.day

\section{- The brine depth levels.}

The effect of three levels of saline water; 2, 4, and $6 \mathrm{~cm}$ was studied. Cover tilt angle was $20^{\circ}$ and feed water was continuous in all previous three levels.

\section{- Slope angle for glass cover.}

The effect of three tilt angle $10^{\circ}, 15^{\circ}$ and $20 \mathrm{o}$ was studied. The brine depth was $2 \mathrm{~cm}$ and feed water was continuous in all previous three angles.

\section{- The time of feed water effect on productivity.}

The effect of three different times of feed water; every one hour, every two hours and every three hours was studied. The brine depth was $2 \mathrm{~cm}$ and tilt angle was $20^{\circ}$ in all previous three feed water systems.

\section{- Coefficient of performance (C.O.P) calculation.}

To test a solar still, or to find out the effect of any modification of the design, it is necessary to determine its coefficient of performance (C.O.P).The most important parameter affecting the output of a solar still is, obviously, the intensity of the solar incident radiation (I) on the still.

I. (in $\mathrm{W} / \mathrm{m}^{2}$.day) is the amount of solar energy incident on the glass cover of a still. Qe: (in $\mathrm{W} / \mathrm{m}^{2}$.day) is the energy utilized in vaporizing water in the still. The rate of distillation $\mathbf{D}$ (lit $/ \mathrm{m}^{2}$.day) produced by the still per unit area of the cover depends on the time of day. Its instantaneous value is given as follows: $\quad D=Q_{\mathrm{e}} / \mathbf{L}_{\mathbf{w g}}$

Where: $\mathrm{L}_{\mathrm{wg}}(\mathrm{J} / \mathrm{kg})$ is the latent heat of water at the cover temperature .

The coefficient of performance (C.O.P) of the still is given by

$$
\text { C.O.P }=\mathbf{Q}_{\mathrm{e}} / \mathbf{I}
$$

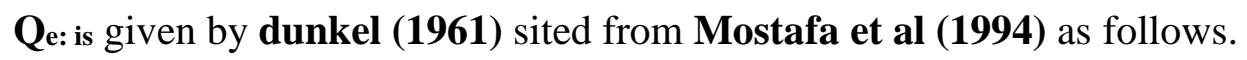


$Q_{e}=0.0061\left[\left(T_{w}-T_{g}\right)+\left(\frac{P_{w}-P_{w g}}{0.265-P_{w}}\right)\left(T_{w}+273\right)\right]^{1 / 3}\left(P_{w}-P_{w g}\right) L_{w}$

Where: $\mathbf{T}_{\mathbf{w}}$ is the average temperature of the water in basin.

$\mathbf{T}_{\mathbf{g}}$ : is the average temperature of the glass cover.

$\mathbf{P}_{\mathrm{w}}$ and $\mathbf{P}_{\mathrm{wg}}:\left(\mathrm{MN} / \mathrm{m}^{2}\right)$ are the partial pressures of water at $\mathrm{T}_{\mathrm{w}}$ and $\mathrm{T}_{\mathrm{g}}\left({ }^{\circ} \mathrm{C}\right)$ respectively.

$\mathbf{L}_{\mathrm{w}}$ : is the latent heat of evaporation of water $(\mathrm{J} / \mathrm{kg})$ at saturation temperature $\mathrm{T}_{\mathrm{w}}$.

\section{- Method of cost evaluation:}

For a distillation unit the, major items of cost per would be:

(a) The total fixed costs as annual percentage of investment,

(b) Cost of supplying saline water to the distiller, and

(c) Operating labor and supervision expenses.

Malik et al.(1982) suggested the following equations to calculate cost:

$$
C=\frac{10 \times I \times(I A+M R+T I)+1000(O, C+S)}{A(Y d+Y r)}
$$

Where:

$\mathbf{C}=$ Cost of water, dollars/1000 gallons (L.E. $/ \mathrm{m}^{3}$ in our study).

$\mathbf{I}=$ Total capital investment, dollars $/ \mathrm{m}^{3}\left(\right.$ L.E. $\left./ \mathrm{m}^{3}\right)$. The following concepts are considered in estimating the capital costs:

1- The construction cost.

2- Manufacturing, erection and supervision cost are estimating about 35\% of the construction cost .

IA = Annual interest and amortization rate, percentage of investment.(the bank interest in Egypt), which was about $11 \%$.

MR = Annual maintenance and repair labor and materials (3\% of the capital cost ).

TI = Annual taxes and insurance charges (zero).

$\mathbf{O}=$ Annual operation labor (3650man.hour).

' $\mathbf{C}=$ Operating labor wage, (1.5 pound/man .hour). Add one pound per day to electric for air blow or suction unit.

$\mathbf{Y}_{\mathbf{y}}=$ Annual unit yield of distilled water (1595.05, 2148.692, 1834.125 and $1981.95 \mathrm{Lit} / \mathrm{m}^{2}$.year) with control unit, preheating unit, air blow unit and air suction unit respectively. 
$\mathbf{Y}_{\mathbf{r}}=$ Annual unit yield of collected rainwater $\left(\mathrm{Lit} / \mathrm{m}^{2}\right)$. Which is about zero in almost area in Egypt, and would be neglected.

$\mathbf{A}=$ Area of distiller on which yield are based (to produce one cubic meter per day is $228.8 \mathrm{~m}^{2}$ of control unit).With preheating unit, takeout $10 \%$ from area to flat plate collector.

$\mathbf{S}=$ Total cost (fixed and operating) of salt water supply, dollars / 1000 gallon (L.E. $/ \mathrm{m}^{3}$ ). Total cost of salt water supply (zero).

\section{RESULTS AND DISCUSSION}

\section{-Effect of brine depth:}

Fig. (3) shows the relation between the productivity rate (Y) of four units and local time at brine depth $2 \mathrm{~cm}$. The productivity (Y) increased as local time increased and reached their maximum values (800, 995, 880 and 940 $\mathrm{cm}^{3} / \mathrm{m}^{2}$.h) with control unit, preheating unit, air blower unit and air suction unit respectively, at about 13 O'clock. The daily productivity were $\left(4370,5903,5025\right.$ and $5430 \mathrm{~cm}^{3} / \mathrm{m}^{2}$.day) with control unit, preheating unit, air blow unit and air suction unit respectively. The highest productivity was with used preheating unit and the lowest productivity was with used control unit. This result maybe attributed to the water feeding temperature in preheating was higher than water temperature feed of other units. In addition, high productivity of air suction may be with the lowest pressure in the still.

Figs. (4 and 5) show that the relation between productivity of four units and local time at brine depth $4 \mathrm{~cm}$ an $6 \mathrm{~cm}$ had the same mentioned trend, but the highest productivity was at used brine depth $2 \mathrm{~cm}$.

Figs.(6) Shows the coefficient of performance (C.O.P.) of four units during the daytime with brine depth $2 \mathrm{~cm}$. The (C.O.P.) of all stills had been increased gradually, and reached to the maximum value at 13 O'clock.

Figs. (7 and 8) give the same trend. but the high values were with brine depth $2 \mathrm{~cm}$.

The relation between measured productivity (Y) and calculated productivity (D) was as the following equation:

$$
\mathbf{Y}=\mathbf{a} \mathbf{D}
$$

Where: "a" parameter depending on brine depth and unit type 
Table (1) shows the values of parameter (a) and $\mathrm{R}^{2}$ at brine depths 2, 4 and $6 \mathrm{~cm}$.
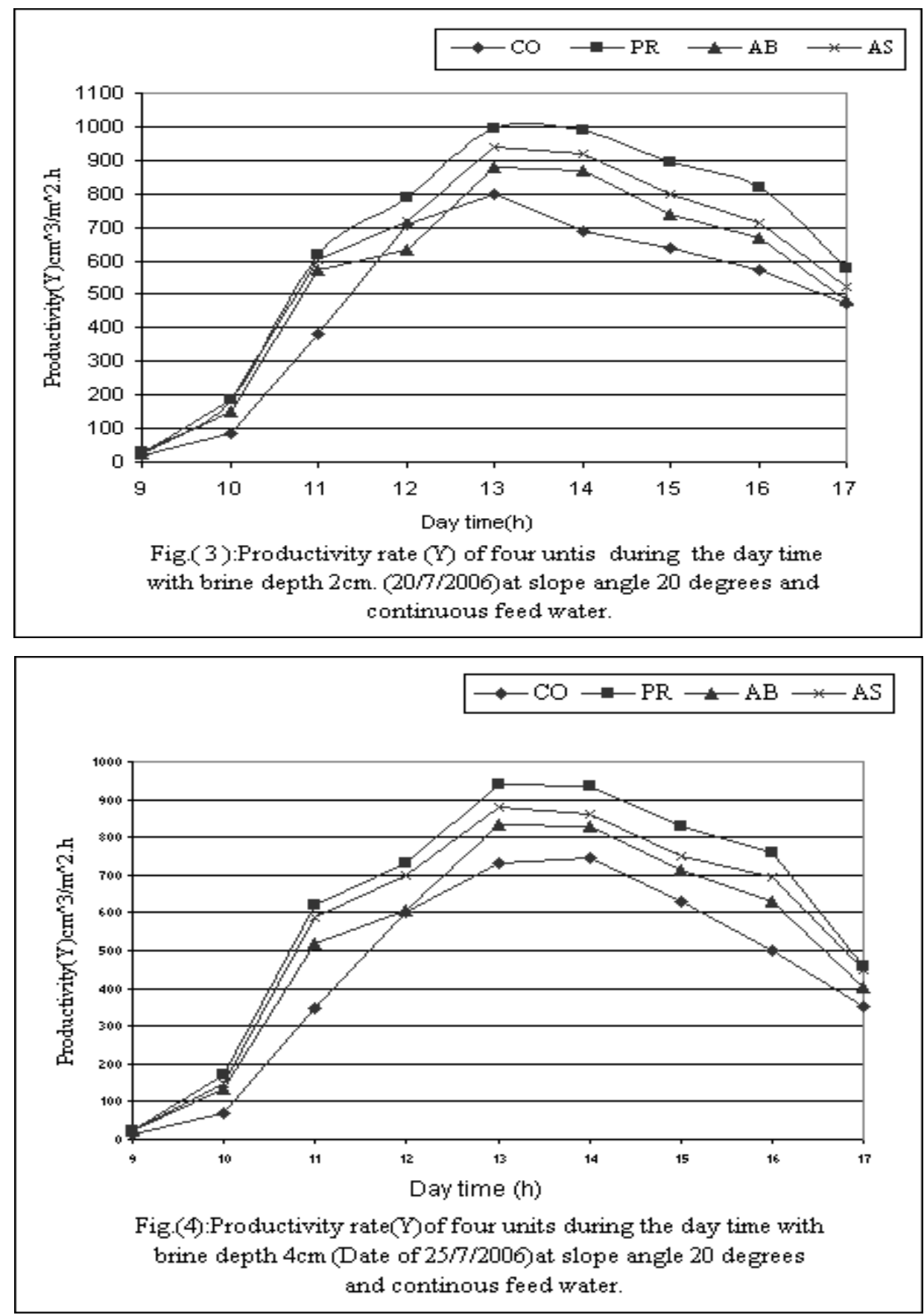

Misr J. Ag. Eng., January 2009 

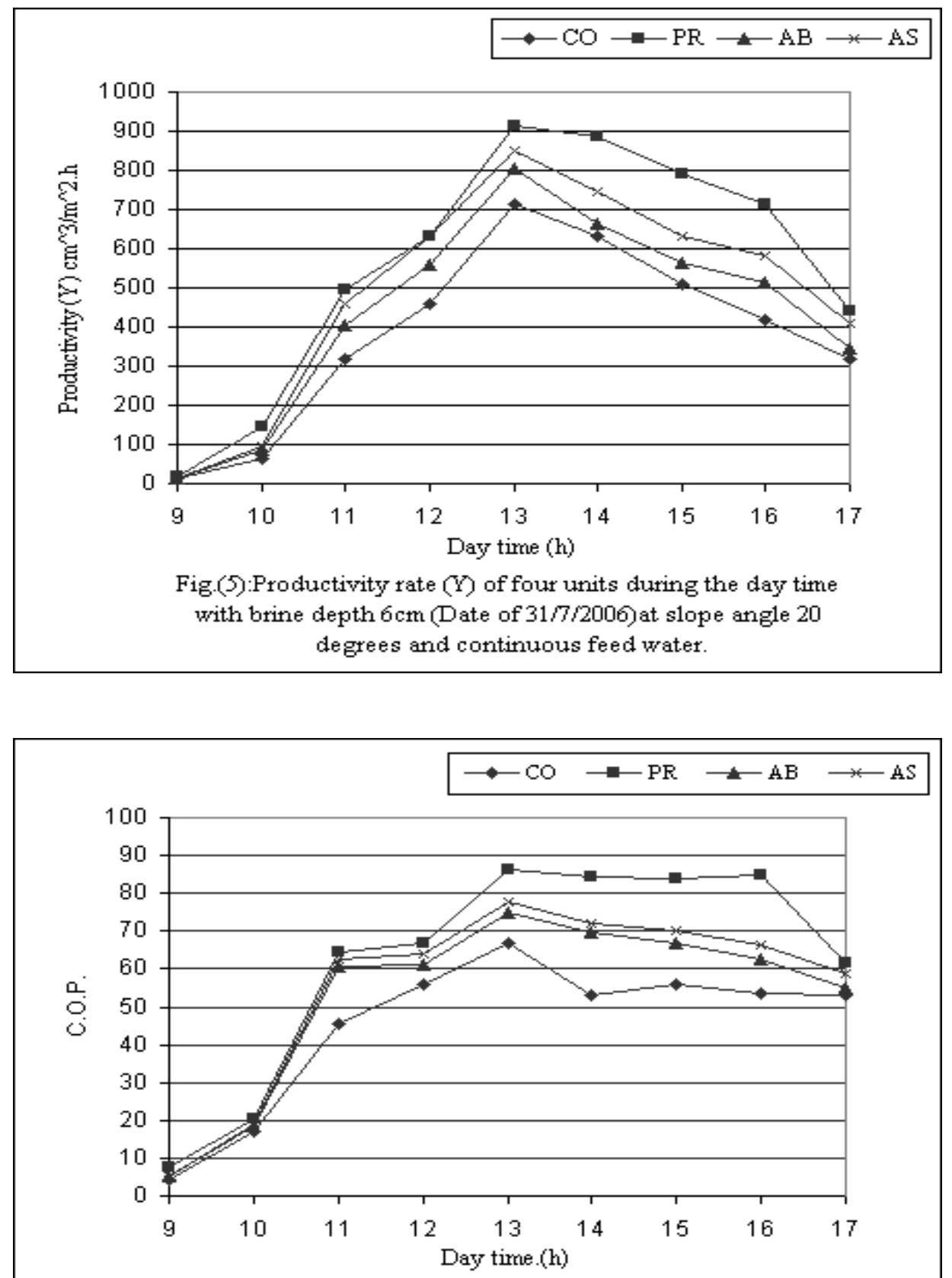

Fig.(6): C.O.P. of four units during the day time with brine depth $2 \mathrm{~cm}$.(date of 20/7/2006) at slope angle 20 degrees and continuous feed water. 

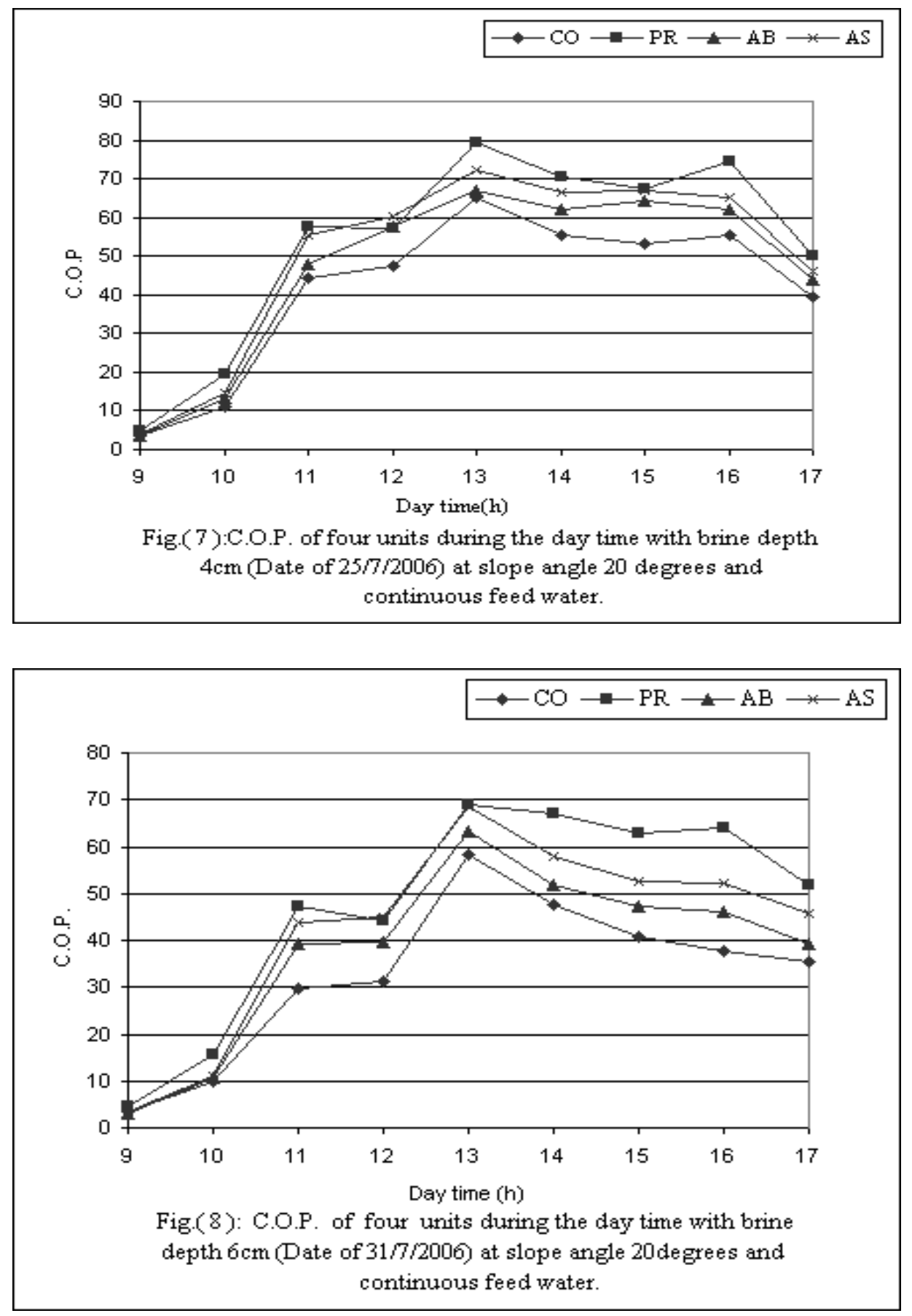

Misr J. Ag. Eng., January 2009 
Table (1): Values of parameter (a) and $\mathrm{R}^{2}$ with brine depth 2,4 and $6 \mathrm{~cm}$

\begin{tabular}{|c|c|c|c|}
\hline \multirow{2}{*}{ unit type } & $\begin{array}{c}\text { depth } \\
\text { (cm) }\end{array}$ & $\mathbf{a}$ & $\mathbf{R}^{\mathbf{2}}$ \\
\hline \multirow{4}{*}{ CO } & 2 & 0.8073 & 0.9136 \\
\cline { 2 - 4 } & 4 & 0.8194 & 0.9574 \\
\cline { 2 - 4 } & 6 & 0.9004 & 0.9658 \\
\hline \multirow{4}{*}{ PR } & 2 & 0.7969 & 0.9837 \\
\cline { 2 - 4 } & 4 & 0.8734 & 0.9799 \\
\cline { 2 - 4 } & 6 & 0.9293 & 0.9886 \\
\hline \multirow{4}{*}{ AB } & 2 & 0.8175 & 0.9607 \\
\cline { 2 - 4 } & 4 & 0.8473 & 0.9630 \\
\hline \multirow{3}{*}{ AS } & 6 & 0.8991 & 0.9855 \\
\hline & 2 & 0.8277 & 0.9700 \\
\hline & 4 & 0.8575 & 0.9756 \\
\hline & 6 & 0.8973 & 0.9782 \\
\hline
\end{tabular}

\section{- Effect of slope angle for glass cover:}

Fig. (9) shows the relation between the productivity rate (Y) of four units and local time at slope angle $20^{\circ}$. The productivity ( Y ) increased as local time increased and reached their maximum values (785, 980, 900, and $935 \mathrm{~cm}^{3} / \mathrm{m}^{2}$.h) with control unit, preheating unit, air blower unit and air suction unit respectively, at about 13 O'clock. The daily productivity was (4382, 5885, 5035 and $5423 \mathrm{~cm}^{3} / \mathrm{m}^{2}$.day) with control unit, preheating unit, air blow unit and air suction unit respectively.

Figs. (10 and 11) indicated that the relation between productivity and local time at slope of cover $15^{\circ}$ and 10 were the same mention trend, also daily productivity and coefficient of performance (C.O.P) in figure (12, 13 and 14)take the same trend, but the highest value was at slope angle of glass cover $20^{\circ}$.

The relation between measured productivity $(\mathrm{Y})$ and calculated productivity (D) was as following equation:

\section{$\mathbf{Y}=\mathbf{a} \mathbf{D}$}

Table (2) shows the values of parameter (a) and $\left(\mathrm{R}^{2}\right)$ at slope angle for glass cover $\left(20^{\circ}, 15^{\circ}\right.$ and $\left.10^{\circ}\right)$. 


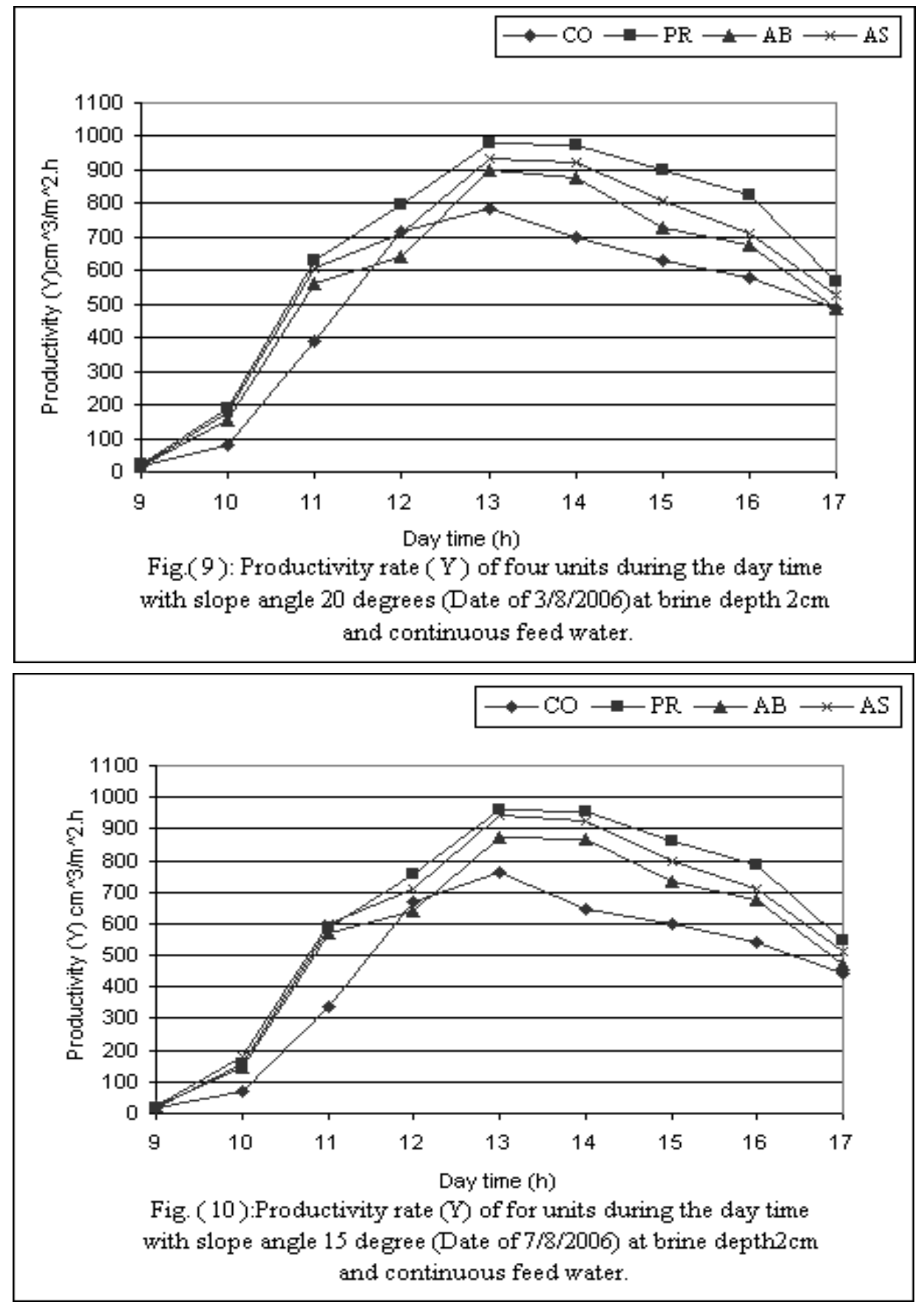

Misr J. Ag. Eng., January 2009 

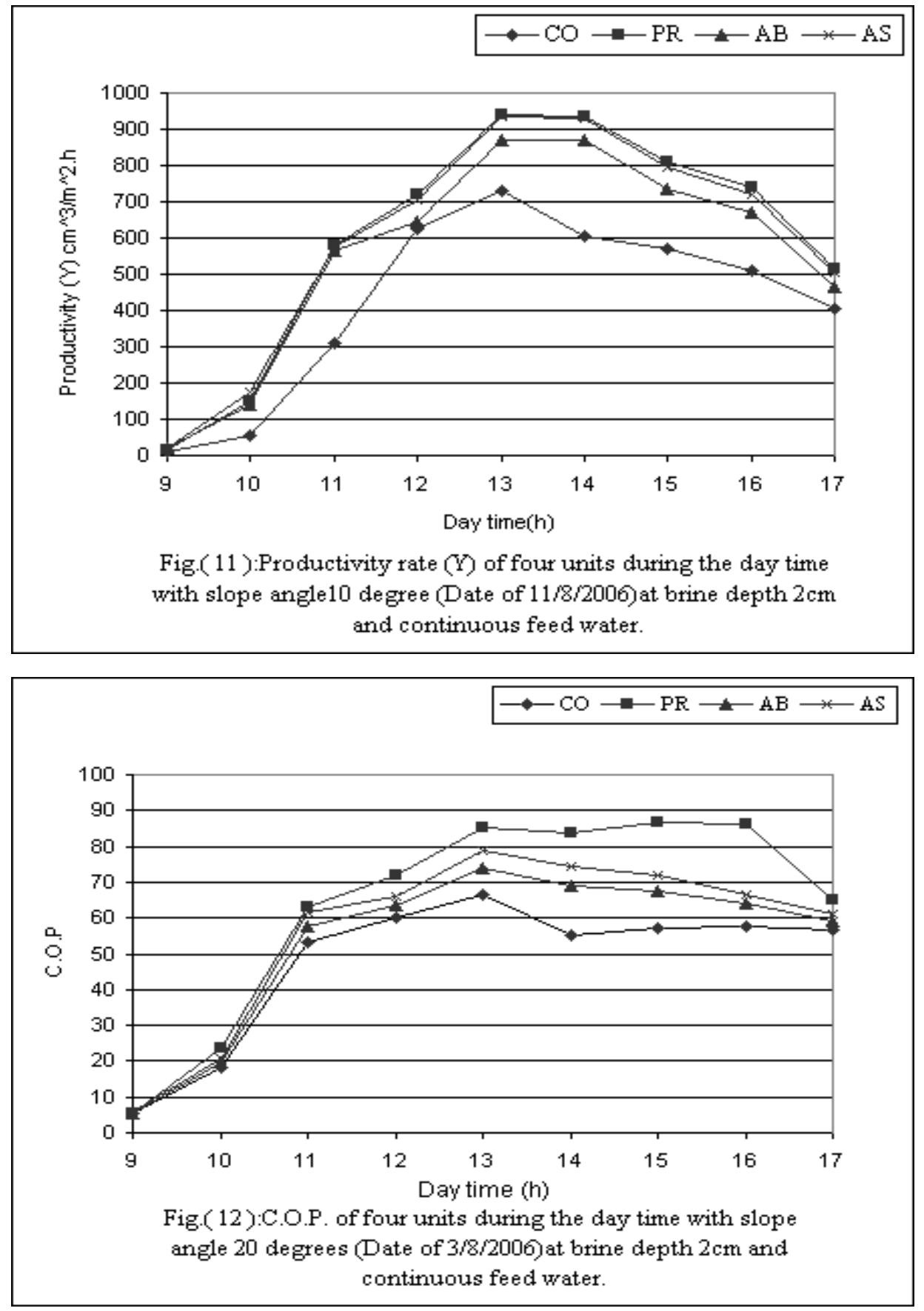

Misr J. Ag. Eng., January 2009 

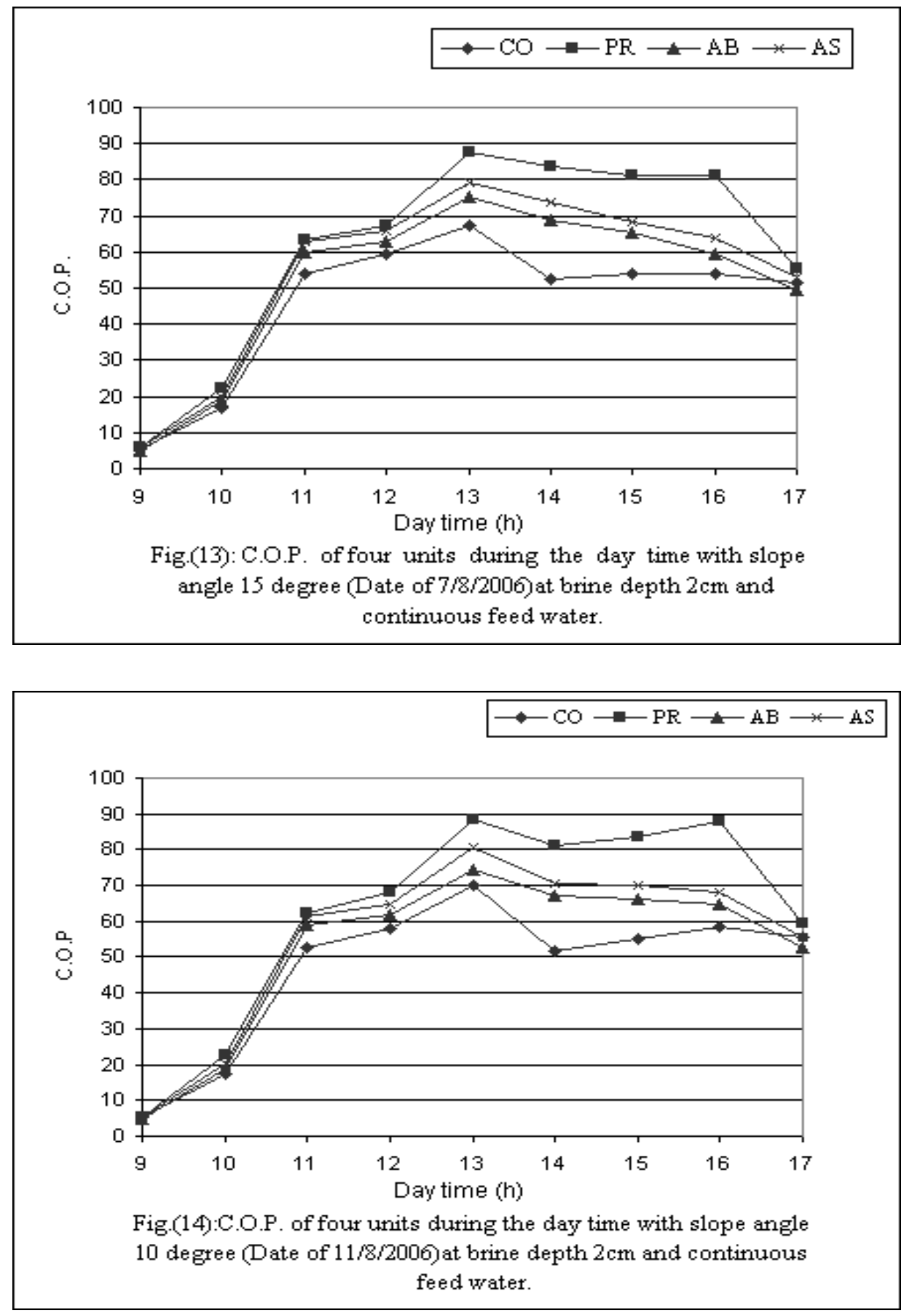

Misr J. Ag. Eng., January 2009 
Table (2): Values of parameter (a) and the $\mathrm{R}^{2}$ at slope angle of glass cover $20^{\circ}, 15^{\circ}$ and $10^{\circ}$.

\begin{tabular}{|c|c|c|c|}
\hline \multirow{2}{*}{ unit type } & $\begin{array}{c}\text { slope } \\
\text { angle }\end{array}$ & $\mathbf{a}$ & $\mathbf{R}^{\mathbf{2}}$ \\
\hline \multirow{4}{*}{$\mathbf{C O}$} & $20^{\circ}$ & 0.8084 & 0.9276 \\
\cline { 2 - 4 } & $15^{\circ}$ & 0.7560 & 0.9194 \\
\cline { 2 - 4 } & $10^{\circ}$ & 0.7137 & 0.9166 \\
\hline \multirow{4}{*}{$\mathbf{P R}$} & $20^{\circ}$ & 0.7998 & 0.9869 \\
\cline { 2 - 4 } & $15^{\circ}$ & 0.7684 & 0.9857 \\
\cline { 2 - 4 } & $10^{\circ}$ & 0.7338 & 0.9845 \\
\hline \multirow{3}{*}{ AB } & $20^{\circ}$ & 0.8209 & 0.9612 \\
\cline { 2 - 4 } & $15^{\circ}$ & 0.8076 & 0.9594 \\
\cline { 2 - 4 } & $10^{\circ}$ & 0.8074 & 0.9599 \\
\hline \multirow{3}{*}{$\mathbf{A S}$} & $20^{\circ}$ & 0.8331 & 0.9696 \\
\cline { 2 - 4 } & $15^{\circ}$ & 0.8251 & 0.9710 \\
\cline { 2 - 4 } & $10^{\circ}$ & 0.8210 & 0.9683 \\
\hline
\end{tabular}

\section{-Effect of feed water time:}

Fig. (15) Shows the relation between the productivity rate (Y) of four units and local time at feed water every one hour. The productivity (Y) increasing as local time increased and reached their maximum values (775, 990, 810, and $930 \mathrm{~cm}^{3} / \mathrm{m}^{2}$.h) with control unit, preheating unit, air blower unit and air suction unit respectively, at about 13 O'clock. The daily productivity was $\left(4315,5930,4888\right.$ and $5350 \mathrm{~cm}^{3} / \mathrm{m}^{2}$.day) with control unit, preheating unit, air blow unit and air suction unit respectively.

Fig. (16 and 17) show relation between the productivity rate (Y) and local time at feed water every two and three hours with four units, the results had the same trends. Also daily productivity had the same trend but the high daily productivity value was (6030) at two hours with preheating unit.

Fig. (18) shows the coefficient of performance (C.O.P.) of four units during the daytime with feed water every one hour. The (C.O.P.) of all stills had been increased gradually, and reached the maximum value at 13 O'clock. 

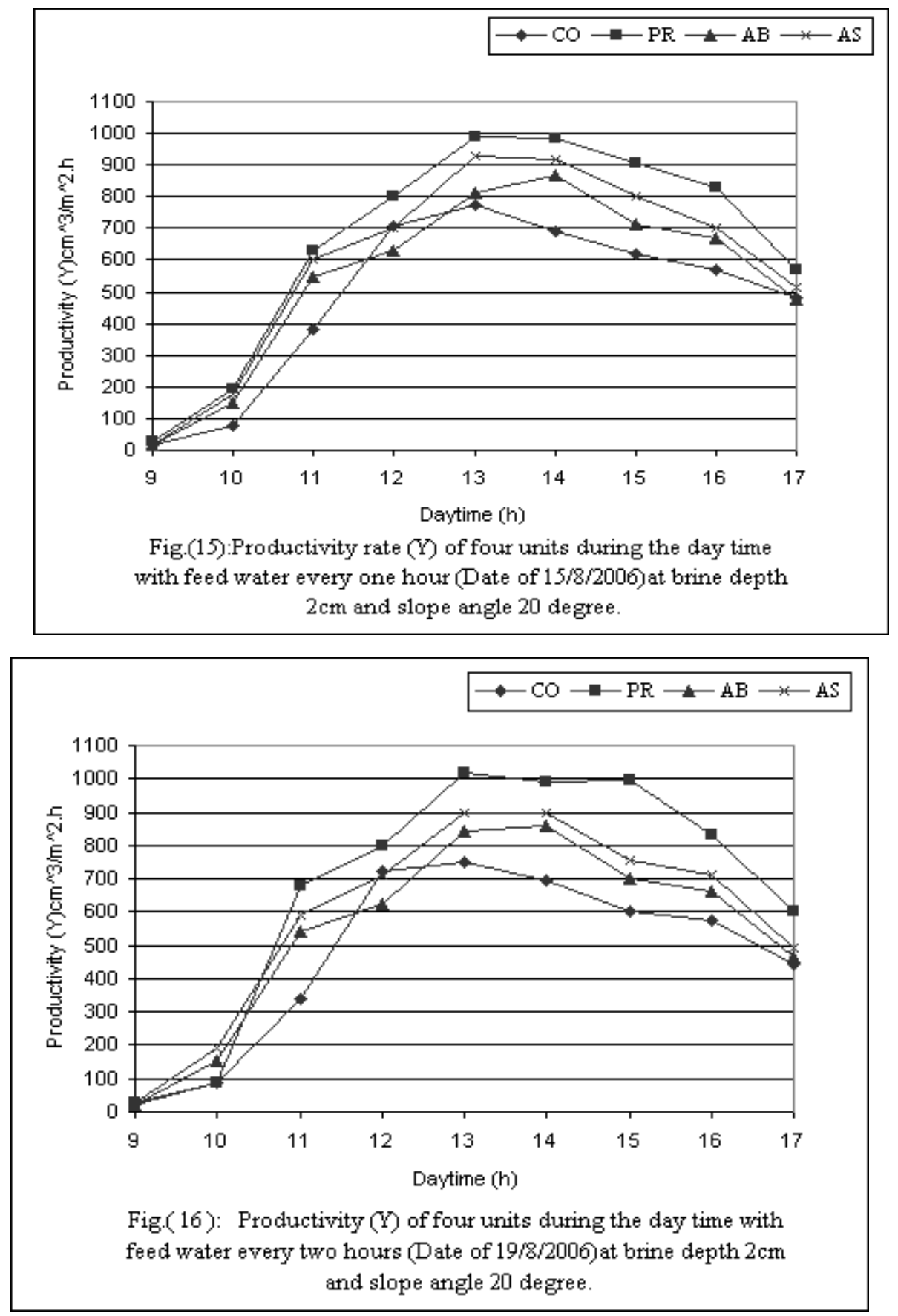

Misr J. Ag. Eng., January 2009 

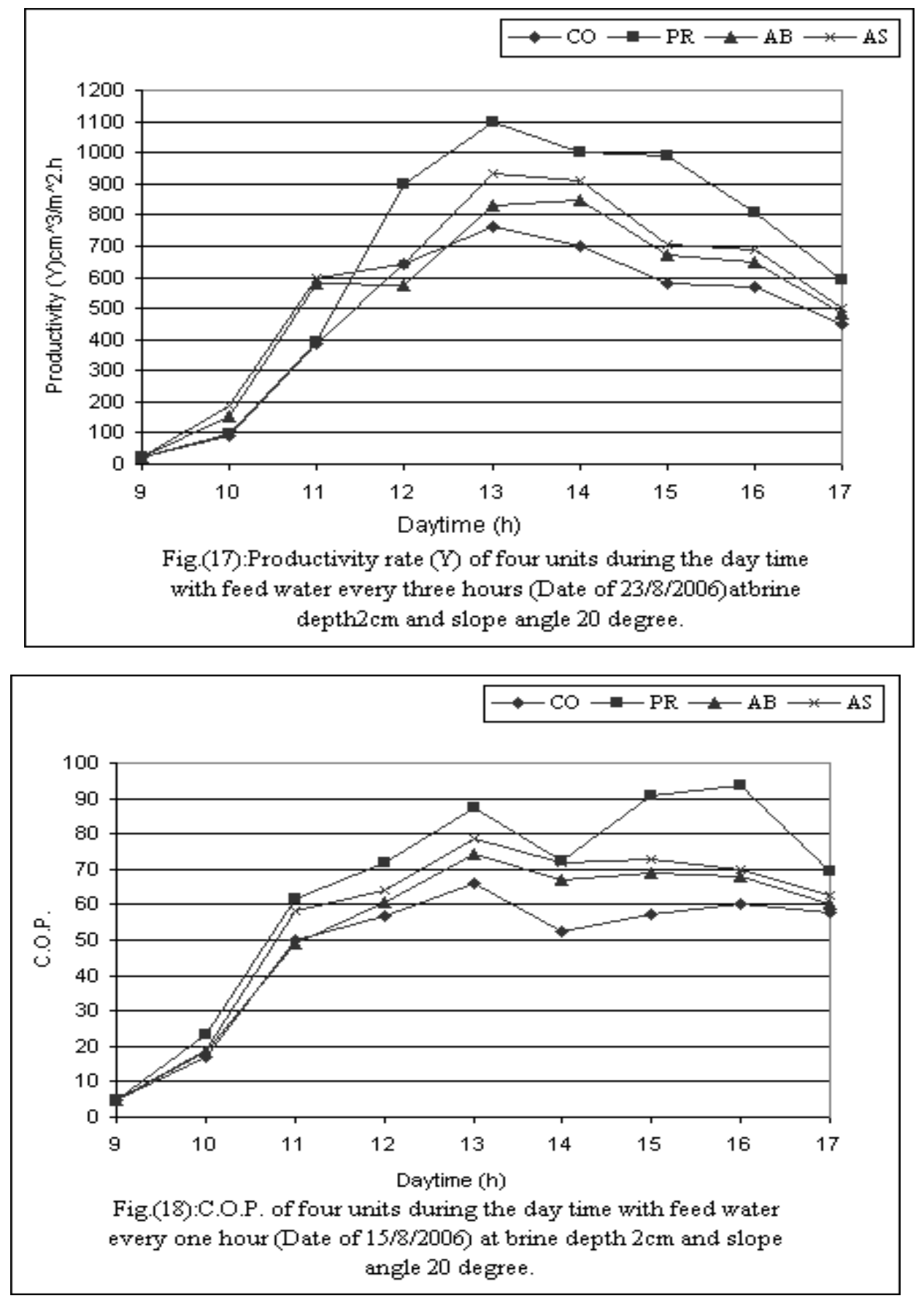

Misr J. Ag. Eng., January 2009 
Figs. (19 and20) give the same results with feed water every two and three hours.

The relation between measured productivity (Y) and calculated productivity (D) was fitted as mentioned by this equation: (Y= $\mathbf{a D}$ ).

Table (3) shows the values of parameter (a) and $\mathrm{R}^{2}$ at feed water every (1, 2 and 3 hours).

Table ( 3 ): Values of parameter(a) and $R^{2}$ with feed water every one hour, two hours, three hours.

\begin{tabular}{|c|l|c|c|}
\hline \multirow{2}{*}{ unit type } & \multicolumn{1}{|c|}{$\begin{array}{c}\text { feed } \\
\text { water }\end{array}$} & a & $\mathbf{R}^{\mathbf{2}}$ \\
\hline \multirow{4}{*}{ CO } & one hour & 0.8164 & 0.9223 \\
\cline { 2 - 4 } & two hours & 0.8037 & 0.9183 \\
\cline { 2 - 4 } & three hours & 0.8073 & 0.9023 \\
\hline \multirow{4}{*}{ PR } & one hour & 0.7953 & 0.9876 \\
\cline { 2 - 4 } & two hours & 0.8159 & 0.9763 \\
\cline { 2 - 4 } & three hours & 0.8273 & 0.9599 \\
\hline \multirow{4}{*}{ AB } & one hour & 0.8062 & 0.9496 \\
\cline { 2 - 4 } & two hours & 0.7966 & 0.9571 \\
\cline { 2 - 4 } & three hours & 0.7901 & 0.9559 \\
\hline \multirow{3}{*}{ AS } & one hour & 0.8370 & 0.9702 \\
\cline { 2 - 4 } & two hours & 0.8578 & 0.9783 \\
\cline { 2 - 4 } & three hours & 0.7979 & 0.9702 \\
\hline
\end{tabular}

\section{-Cost evaluation of solar distillation:}

The performance of solar still is generally expressed as the quantity of water produced by unit of basin area in a day.

To produce one cubic meter of distilled water, by substituting all values in the equation, the costs were:

-Control unit: Cost $=15.3$ L.E. $/ 1000$ lit or 15.3 L.E. $/ \mathrm{m}^{3}$.

- Preheating unit:Cost $=12.63$ L.E. $/ 1000$ lit or 12.63 L.E. $/ \mathrm{m}^{3}$.

- Air blow unit: Cost $=14.33$ L.E. $/ 1000$ lit or 14.33 L.E. $/ \mathrm{m}^{3}$.

- Air suction unit: Cost = 13.26L.E./1000 lit or 13.26 L.E. $/ \mathrm{m}^{3}$. 


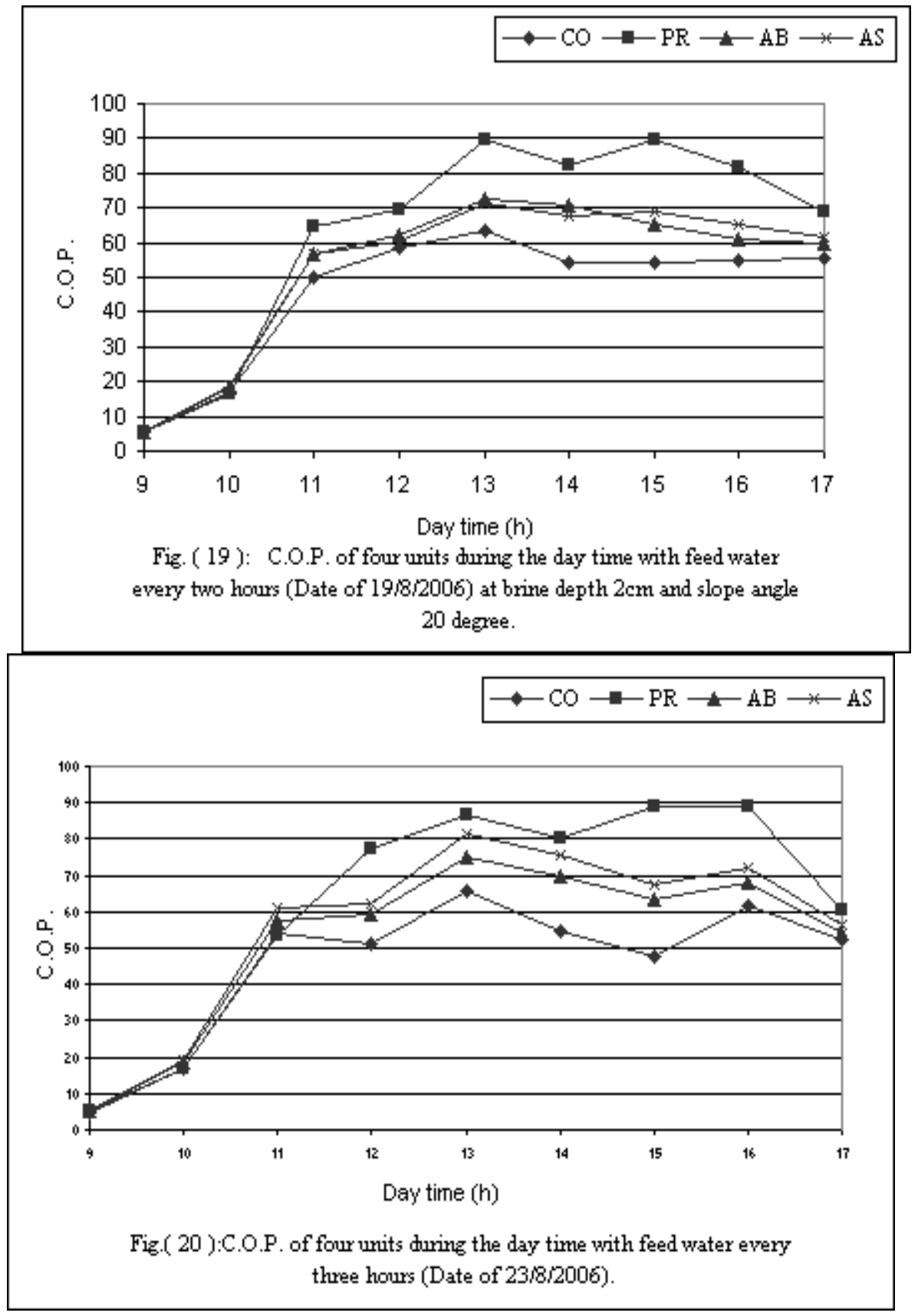

\section{CONCLUSION}

The aim of this study is to design and evaluate solar still for desalination of sea water with optimum efficiency. Four units of solar stills were 
constructed as the follows: (control unit, preheating unit, air blower unit and air suction unit).Some parameters, which affect on productivity of solar still units were studied such brine depth, slope angle of glass cover and feed water. The results indicate the following:

\section{Solar intensity and ambient air temperature:}

The solar intensity reaches maximum value at noon (about 13 O'clock) then it starts to decrease. The fluctuations, in the solar heat flux were due to the instability of the weather conditions during the day. The nature of the incident solar heat flux has significant effects on the thermal performance of the solar still. The ambient air temperature increased and reached its maximum value at about 14 O'clock, and then it began to decrease again.

\section{Effect of some parameter on productivity of four still units:}

\section{- Effect of brine depth:}

Experiments were carried out for brine depths (2, 4 and $6 \mathrm{~cm}$ ).It was found that the highest productivity $(\mathrm{Y})$ was with brine depth $2 \mathrm{~cm}$, as follows: At brine depths $(2,4$ and $6 \mathrm{~cm})$ the daily productivity $\left(\mathrm{Y}_{\mathrm{d}}\right)$ for control unit were $\left(4370,3985\right.$ and $3453 \mathrm{~cm}^{3} / \mathrm{m}^{2}$.day) respectively. The daily productivity for preheating unit were (5903, 5469 and 5035 $\mathrm{cm}^{3} / \mathrm{m}^{2}$.day) respectively. The daily productivity for air blower unit were (5025, 4697 and $3959 \mathrm{~cm}^{3} / \mathrm{m}^{2}$.day) respectively and the daily productivity for air suction unit were $\left(5430,5098\right.$ and $4415 \mathrm{~cm}^{3} / \mathrm{m}^{2}$.day) respectively.

\section{--Effect of slope angle of glass cover:}

Experiments were carried out for brine depths $20^{\circ}, 15^{\circ}, 10^{\circ}$. The results indicate the following: At slope angles $\left(20^{\circ}, 15^{\circ}\right.$ and $\left.10^{\circ}\right)$ the daily productivity $\left(\mathrm{Y}_{\mathrm{d}}\right)$ for control unit were $\left(4382,4080\right.$ and $3820 \mathrm{~cm}^{3} / \mathrm{m}^{2}$.day) respectively. The daily productivity for preheating unit were $(5885,5625$ and $5405 \mathrm{~cm}^{3} / \mathrm{m}^{2}$.day) respectively and the daily productivity for air blower unit were $\left(5035,5005\right.$ and $4980 \mathrm{~cm}^{3} / \mathrm{m}^{2}$.day) respectively and the daily productivity for air suction unit were (5423, 5400 and 5360 $\mathrm{cm}^{3} / \mathrm{m}^{2}$.day) respectively.

\section{-Effect of feed water time:}

Experiments were carried out for (every one hour, two hours and three hours).The results indicate the following: At feed water every (1, 2 and 3 hour) the daily productivity $\left(\mathrm{Y}_{\mathrm{d}}\right)$ for control unit were $(4315,4232$ and 
$4198 \mathrm{~cm}^{3} / \mathrm{m}^{2}$.day) respectively. The daily productivity for preheating unit were $\left(5930,6030\right.$ and $5900 \mathrm{~cm}^{3} / \mathrm{m}^{2}$.day) respectively. The daily productivity for air blower unit were $\left(4888,4872\right.$ and $4815 \mathrm{~cm}^{3} / \mathrm{m}^{2}$.day) respectively and the daily productivity for air suction unit were (5350, 5272 and $5194 \mathrm{~cm}^{3} / \mathrm{m}^{2}$.day) respectively.

\section{Cost evaluation:}

To produce one cubic meter of distilled water, the costs were $(15.3,12.63$, 14.33 and $13.26 \mathrm{~L} . \mathrm{E} / \mathrm{m}^{3}$ ) at control unit, preheating unit, air blower unit and air suction unit) respectively.

\section{REFERANCES}

Ahmed, G.E. and J. Schmid, (2002). Feasibility study of brackish water desalination in the Egyptian deserts and rural regions using pv systems. Energy-conversion-and-management. Vol.43, No18: 2641 - 2649.

Abdel-Salam, A.Z. (1996). Liquid dispersion in collector humidifiers for solar desalination cycle.Ph.D.Th., Mech .Eng.Dept.,Fac.,of Eng.zagazig univ.

Badr, M.M. (2008). Solar energy utilization in water distillation. M.Sc.th., Agric. Eng. Dept., Fac., of Agric., Al-azhar Univ.

Delyannis, E. (2003). Historic background of desalination and renewable energies, Solar Energy, (www.elsevier.com /locate/solener), Vol.75, 357-366.

Ghandour, A.F. (2001). Use solar energy for water distillation. ph. D. Th., Eng. Dept., Fac., of Agric., Zagazig Univ.

Ghoraba, M.M. (1987). Theoretical and experimental studies of heat and mass transfer inside single sloped solar stills .Ph. D. Th., Fac., of Eng ., Cairo Univ., Egypt

Hasan, A. and A.M. sayigh, (1992). The effect of sand dust accumulation on the light transmittance, reflection, and absorbance of the PV glazing-In: Sayigh A.A.M(Ed), Renewable Energy, Technology and Environment. Pergamon press, Oxford,: 461-466.

Mathioulais, E. and V. Belessiotis, (2003). Integration of solar still in amult - source, multi - use environment. Solar Energy, (www.elsevier.com/locate/solener), Vol. 75, 403-411. 
Mostafa, M.E.; S.T. Ibrahim and A.S. Jaffar, (1994). "Design of solar thermal systems". Sci. Publ. Center, King Abdulziz Univ.. Saudi Arabia: 187-252.

Mourad, R.I. (2005). Solar extraction of Soil moisture. Misr, J.ag. Eng., Vol. 22. No2:351-361.

Rajvanshi, A.K. (1981). Effect of various dyes on solar distillation. Solar Energy, (www.elsevier.com/locate/solener), Vol. 27, 51-65.

Rai, S.N. and G.N. Tiwar, (1983). Single basin solar still coupled with flat-plate collector. Solar Energy Conversion and Manag., Vol. 23, No. 3: 145-149.

Talbert, S.C.; J.p. Eibling and G.D. lof, (1970). Manual on solar distillation of saline water, U.S. Dept. of the Interior, O.S.W., Report No.546.

Zabady, F.I. (1997). Possibility of using solar energy in irrigation. M. Sc. th., Agric. Eng. Dept., Fac., of Agric., AL-Azhar Univ.

$$
\text { استخدام الطاقة الثمسية فى تحلية المياه }
$$

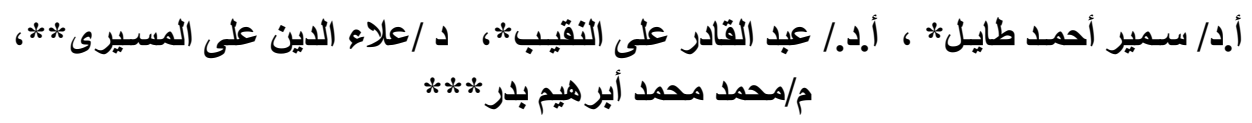

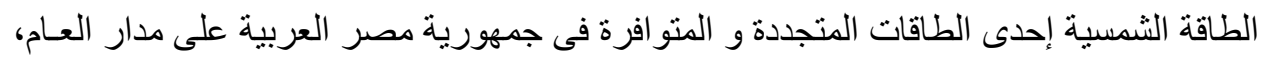

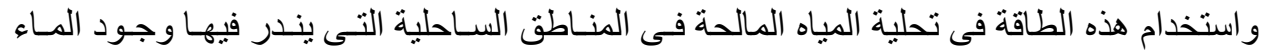

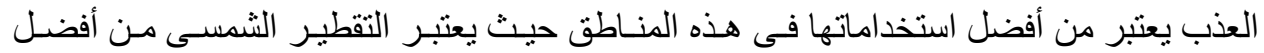
الطرق و أرخصها لتحلية المياه المالحة لما له من تأثير نظيف الفئ على البيئة. تهدف هذه الدر اسة لتصميم و تقييم بعض المقطر ات الثمسية لتحلية المياه المالحة من خلال بعض المضاه

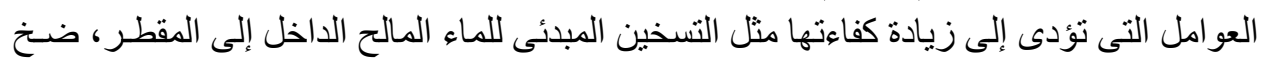

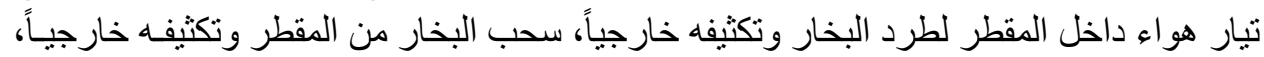

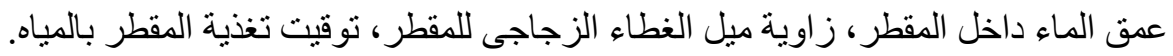

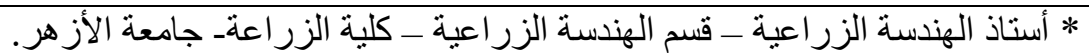

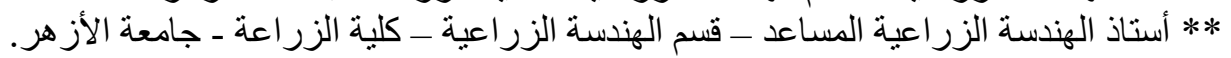

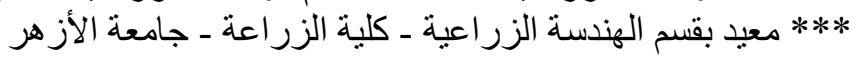


صمم للنلك أربع وحدات تقطير شمسى وهم كالتالى:

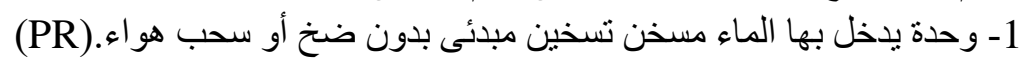

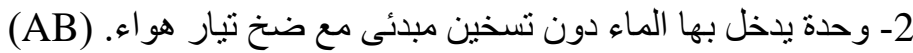

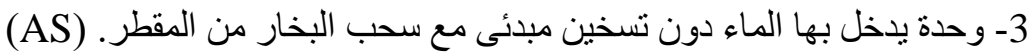

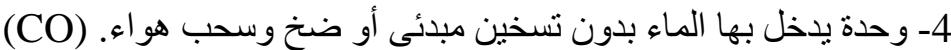

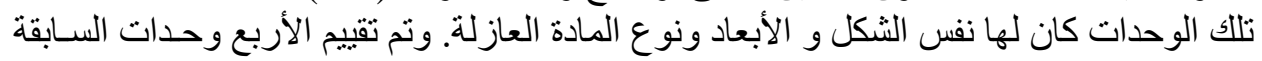

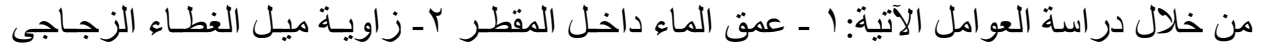

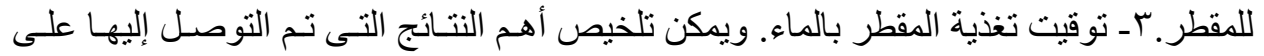

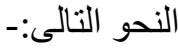

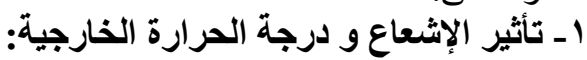

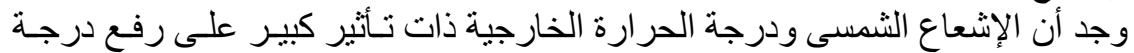

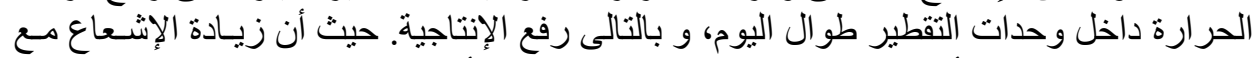

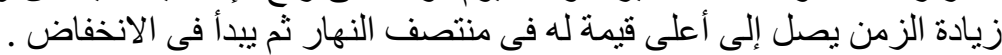

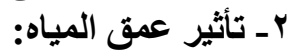

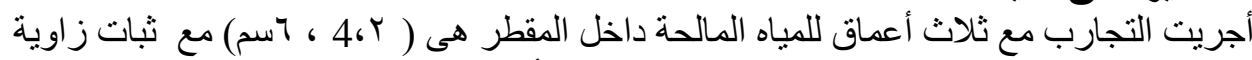

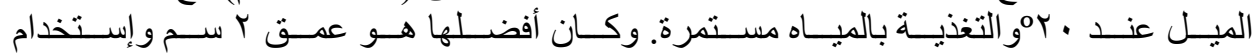
وحدة preheating ب-تأثير زاوية ميل الغطاء الزجاجى:

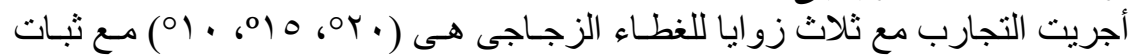
العمق عند آسم و تغذية المياه مستمرة. رغم رغ أن زويا الميل أعطت إختلاف لايذكر إلا أن زاويـة

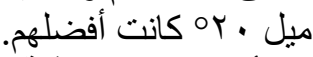
r-تأثير توقيت التظذية بالماء المالح:

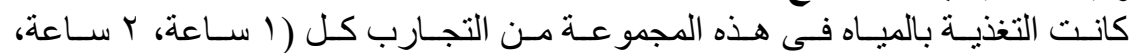

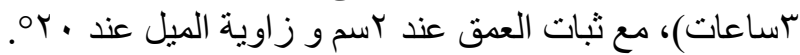

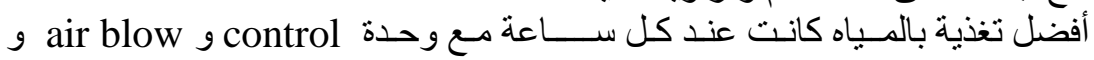

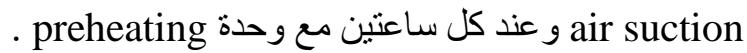

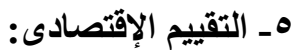

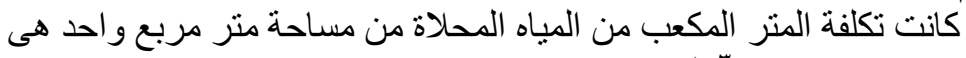

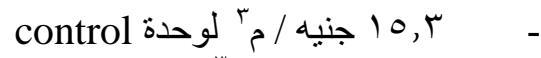
preheating air suction - 